\title{
KONSENTRASI MERKURI PADA AIR SUNGAI DAN SEDIMEN SUNGAI DESA TAMBANG SAWAH AKIBAT PENAMBANGAN EMAS TANPA IZIN
}

\section{Mercury Concentrations of River Water and Sediment in Tambang Sawah Village Due to Unlicensed Gold Mining}

\author{
Irwan Mulyadi*, Badrus Zaman, Sri Sumiyati \\ Program Magister Teknik Lingkungan, Fakultas Teknik, Universitas Diponegoro \\ *Email : irwanmulyadi12@gmail.com
}

Received : 7 Juli 2020; Accepted : 25 Juli 2020; Publish : Juli 2020

\begin{abstract}
ABSTRAK
Banyaknya kegiatan Penambangan Emas Tanpa Izin yang merupakan penambangan rakyat peninggalan kolonial Belanda yang terletak di Desa Tambang Sawah Kabupaten Lebong menimbulkan permasalahan lingkungan khususnya merkuri pada perairan sungai tersebut. Sampel air dan sedimen diambil dari lima titik yang terletak sepanjang hulu hingga batas desa. Konsentrasi merkuri pada air mulai dari hulu sampai hilir sungai batas desa berturutturut adalah $<0,0003 ; 0,0004 ; 0,0007 ; 0,0008$ dan 0,0011 ppm dan konsentrasi merkuri pada sedimen dari hulu sampai hilir sungai batas desa berturut-turut yaitu 1,34;4,18. 35,89; 50,32 dan 114,37 ppm dimana kondisi ini melebihi ambang batas yang ditentukan. Peningkatan konsentrasi merkuri dari hulu sampai hilir sungai ini dikarenakan terjadinya akumulasi kegiatan pertambangan emas rakyat yang menggunakan merkuri dan melepas limbahnya ke sungai.

Kata kunci : Merkuri, Sedimen, Air, Lebong, Tambang Emas,

A lot of activity of Unlicensed Gold Mining, which is the mining of the people of Dutch colonial heritage located in Tambang Sawah, Pinang Belapis, Lebong Regency, has caused environmental problems, especially mercury in the river waters. Water and sediment samples were taken from five points located along the upstream to the village boundary. The concentration of mercury in water from upstream to downstream of the village boundary river are <0,0003;0,0004; 0,0007; 0,0008 and 0,0011 ppm respectively and the concentration of mercury in sediments from upstream to the downstream of the river the village boundary are 1,$34 ; 4,18$. 35,89; 50,32 dan 114,37 ppm respectively where these conditions exceed the specified threshold. The increase in mercury concentration from upstream to downstream of the river is due to the accumulation of community gold mining activities that use mercury and release its waste into the river.
\end{abstract}

Keywords: Mercury, Sediment, water, Lebong, Gold Mining 


\section{PENDAHULUAN}

PETI, istilah yang digunakan terhadap "Penambangan Emas Tanpa Izin " dalam kehidupan sehari hari. Aktivitas yang dilakukan oleh masyarakat pada daerah Tambang Sawah, salah satu desa di Kecamatan Pinang Berlapis dibawah kepemerintahan kabupaten telah berlangsung dari zaman penjajahan Belanda. Proses amalgamasi adalah proses yang digunakan dalam kegiatan PETI ini. Amalgamasi, suatu proses pencampuran batuan tambang yang mengandung $\mathrm{Au}$ (emas) dan $\mathrm{Hg}$ (merkuri) dengan menggunakan tromol [1]. Adanya kontak dengan logam merkuri dalam proses amalgamasi menghasilkan limbah yang mengandung merkuri. Dua jenis limbah dihasilkan dari proses ini. Jenis limbah pertama yang dihasilkan adalah Limbah cair. Limbah cair didapatkan dari air limbah kolam penampungan yang akan dialirkan ke sungai. Jenis limbah yang kedua adalah limbah padagt. Limbah padat berasal dari sedimen kering yang diolah dengan senyawaan Sianida ( $\mathrm{NaCN}$ ) yang akan terbawa oleh aliran sungai dalam bentk suspensi.

Air dan sedimen merupakan parameter penting dalam mengontrol keberadaan logam berat yang terkumpul dan menumpuk dalam jaringan tubuh biota perairan [2]. Dalam sistem perairan, sedimen adalah partikel penting yang tenggelamdan tersuspensi serta merupakan sumber Hg. Metil merkuri (MeHg), senyawa yang dihasilkan oleh sdimen dimana sedimen dianggap sebagai penghasil urama senyawa tersebut [3]. Pengukuran terhadap air dan limbah ini menjadi sangat penting terkait dengan kondisi biota perairan. Berdasarkan pemaparan diatas, penelitian ini bertujuan untuk mengukur konsentrasi Merkuri pada air sungai dan sedimen sungai desa Tambang Sawah akibat PETI. Kontaminasi merkuriperlu menjadi perhatian khusus karena belum ada standar baku mengeni Jurnal Ilmiah Teknik Kimia hal ini yeitu konsentrasi logam merkuri pada sedimen sungai[4].

\section{BAHAN DAN METODE}

Penelitian ini dilaksanakan pada awal bulan Februari hingga akhir April 2020, dengan lokasi penelitian di sungai yang melewati Desa Tambang Sawah dan digunakan sebagai badan air penerima pembuangan limbah kegiatan amalgamasi. Sampel yang dianalisa adalah sampel air sungai dan sedimen sungai yang melewati sepanjang Desa Tambang sawah, diambil sebanyak 5 titik, titik pertama dan kedua berada di hulu sungai pada batas desa, titik 3 berada di tengah desa sedangkan titik 4 dan 5 berada di hilir sungai pada batas desa (Gambar 1). Teknik penyamplingan yang dilakukan merujuk pada "Japan Public Health Association" atau lebih dikenal dengan JPHA [5] dimana pipa paralon digunakan sebagai sampling sedimen dan sampel sedimen yang diambil harus berada pada kedalam 10 hingga $15 \mathrm{~cm}$ dari permukaan. Pemisahan sedimen dari pengotor seperti kerikil dan tanaman serta benda pengganggu lain dilakukan terlebih dahulu kemudian difiltrasi menggunakan ayakan berukuran 2 mesh dan disimpan dalam kemasan botol, dilabel dan disegel serta dimasukkan kedalam kotak pendingin untuk dikirim ke laboratorium.

Pengambilan sampel air dilakukan menggunakan sistem "kemerer water sampler" pada kedalaman $20 \mathrm{~cm}$ dan $75 \mathrm{~cm}$ kemudian dikomposit. Sampel air diambil, disimpan dalam botol, diawetkan dengan Asam Nitrat pekat khusus sampel logam berat sebanyak $3 \mathrm{ml}$ dan dilabel ntuk dikirim ke laboratorium. Sampel air sungai dan sedimen sungai dianalisis di Laboratorium Balai Riset dan Standarisasi Industri Padang berdasarkan acuan ASTM C1301-95(2001). 


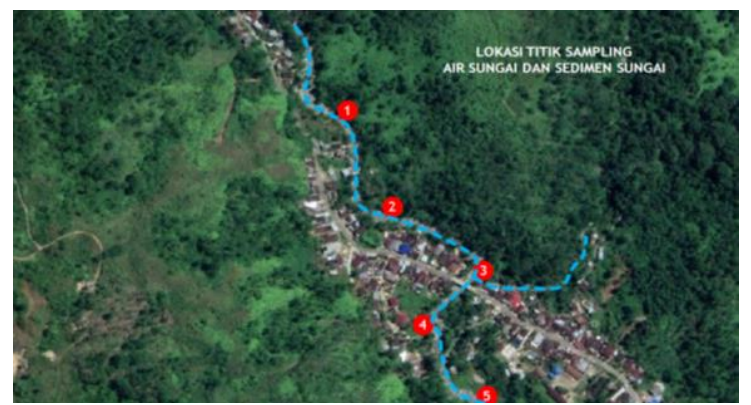

Gambar 1. Gambaran wilayah penyamplingan

\section{HASIL DAN PEMBAHASAN}

Konsentrasi $\mathrm{Hg}$ meningkat seiring dengan bertambahnya jumlah penambang yang membuang air limbah dan limbah tailing ke dalam sungai. Berdasarkan Tabel 1 dapat kita lihat kandungan merkuri tertinggi pada air sungai berada pada lokasi Titik 5 dengan kadar merkuri sebesar 0,0011 ppm, hal ini disebabkan Titik 5 merupakan lokasi atau titik akumulasi aliran sungai yang melewati Desa Tambang Sawah. Untuk Titik 1 sampai dengan Titik 4 kadar merkuri berkisar antara $0,0003-0,0008 \mathrm{ppm}$, nilai tersebut lebih kecil dari lokasi Titik 5 dan dalam kategori memenuhi baku mutu PP No 82 Tahun 2001 tentang Pengelolaan Kualitas Air dan Pengendalian Pencemaran Air (Kelas 1), walaupun masih adanya aktivitas PETI di sekitar lokasi tersebut tetapi kadar merkuri di perairan terdeteksi kecil, hal ini dapat diperkirakan bahwa tidak semua kandungan logam merkuri yang terdeteksi di perairan, karena merkuri memiliki sifat sangat mudah terakumulasi dan mengendap.

Tabel 1. Kadar $\mathrm{Hg}$ dalam Sampel Air Sungai

\begin{tabular}{clcc}
\hline No & $\begin{array}{c}\text { Kode } \\
\text { Sampel }\end{array}$ & $\begin{array}{c}\text { Hasil } \\
\text { Pengukuran }\end{array}$ & $\begin{array}{c}\text { Baku } \\
\text { Mutu*) }\end{array}$ \\
\cline { 1 - 2 } $\mathbf{1}$ & $\begin{array}{l}\text { Air Sungai } \\
\text { (AP 1) }\end{array}$ & $<0,0003$ & 0,001 \\
& $\begin{array}{l}\text { Air Sungai } \\
\text { (AP 2) }\end{array}$ & 0,0004 & \\
& $\begin{array}{l}\text { Air Sungai } \\
\text { (AP 3) }\end{array}$ & 0,0007 & \\
\hline
\end{tabular}

Jurnal Ilmiah Teknik Kimia

\begin{tabular}{clc}
\hline 4 & $\begin{array}{l}\text { Air Sungai } \\
\text { (AP 4) }\end{array}$ & 0,0008 \\
\hline $\mathbf{5}$ & $\begin{array}{l}\text { Air Sungai } \\
\text { (AP 5) }\end{array}$ & 0,0011 \\
\hline
\end{tabular}

*) PP No 82 Tahun 2001 tentang Pengelolaan Kualitas Air dan Pengendalian Pencemaran Air (Kelas 1)

Logam berat merkuri mudah larut dan mengubah kestabilan dari bentuk karbonat menjadi hidroksida yang membentuk ikatan partikel pada perairan, kemudian pengendapan terjadi dan berakhir pad pembentukan lumpur [6]. Logam merkuri tidak mudah terdeteksi. Hal ini dikarenakan pada permukaan perairan karena merkuri memiliki sifat yang mudah mengikat bahan organik dan mengendap di dasar perairan sehingga kemungkinan akan lebih besar kandungan di dalam sedimen. Hal ini juga sejalan dengan pendapat Rochyatun yang mengungkapkan bahwa kadar logam berat dalam sedimen lebih tinggi dibandingkan dalam air karena terakumulasi dari pengendapan dan logam berat di dalam air lebih kecil karena proses pengenceran dan pengaruh pola arus [7].

Tabel 2. Kadar Hg dalam Sampel Sedimen Sungai

\begin{tabular}{|c|c|c|c|}
\hline No & Kode Sampel & $\begin{array}{c}\text { Hasil } \\
\text { Pengukura } \\
\text { n }\end{array}$ & $\begin{array}{c}\text { Baku } \\
\text { Mutu* } \\
*)\end{array}$ \\
\hline 1 & $\begin{array}{l}\text { Sedimen } \\
\text { Sungai (STP 1) }\end{array}$ & 1,3405 & 0,174 \\
\hline 2 & $\begin{array}{l}\text { Sedimen } \\
\text { Sungai (STP 2) }\end{array}$ & 4,1849 & \\
\hline 3 & $\begin{array}{l}\text { Sedimen } \\
\text { Sungai (STP 3) }\end{array}$ & 35,8923 & \\
\hline 4 & $\begin{array}{l}\text { Sedimen } \\
\text { Sungai (STP 4) }\end{array}$ & 50,3214 & \\
\hline 5 & $\begin{array}{l}\text { Sedimen } \\
\text { Sungai (STP 5) }\end{array}$ & 114,3742 & \\
\hline
\end{tabular}

Sedimen dengan konsentrasi Merkuri melebihi 2 ppm dapat dikategorikan kedalam sedimen yang telah terkontaminasi [8]. Berdasarkan penelitian Juli 2020 Vol. 4 No. 2 
ini, pada lokasi Titik 5 menunjukkan nilai kontaminasi $\mathrm{Hg}$ sebesar 114,37 ppm berat kering. Hal ini disebabkan karena di sekitar Titik 5 merupakan area akumulasi merkuri pada aliran sungai yang melewati kegiatan pertambangan emas di Desa Tambang Sawah.

Tingginya kadar merkuri pada sedimen sungai yang melewati Desa Tambang Sawah diduga memiliki hubungan erat dengan keberadaan penambangan emas rakyat (PETI) yang menggunakan teknik amalgamasi yang diduga menjadi penyebab utama kontaminasi merkuri di parairan tersebut.

Merkuri yang ikut terbawa bersamaan dengan sedimen mulai dari hulu emnjadi terakumulasi ketika mencapai daerah muara, hal ini dikarenakan oleh merkuri dan sedimen yang terendapakan dapat membentuk "hot spot" kontaminasi antara estuari dan daerah kegiatan pertambangan, terutama pada aliran yang tidak deras atau topografi dasar sungai yang landai [8].

Penelitian Geologi Medis yang dilakukan pada tahun 2011 menunjukkan angka bahwa kandungan merkuri pada sedimen sungai yang terdapat di Desa Tambang Sawah sebesar 0,292 ppm [9], hal ini menjadi acuan bahwa dalam kurun waktu kurang lebih 9 tahun terjadi peningkatan kandungan merkuri yang sangat besar pada sedimen sungai.

Kadar merkuri yang di dalam air sungai tetap harus mendapat perhatian khusus dalam riset yang berkelanjutan. Merkuri yang terakumulasi secara terus menerus akan meningkatkan pencemaran lingkungan, berdampak buruk bagi kesehatan dan bersifat toksik terhadap manusia. Bentuk molekul dari merkuri yang bersifat toksit terhadap tubuh manusia adalah methyl mercury dan garam organik, partikel mercuri khlor. Methyl mercury terbentuk oleh bakteri yang ada pada endapan dan air yang bersifat asam.

Jurnal Ilmiah Teknik Kimia
Ion merkuri anorganik adalah bentuk dari molekul merkuri yang bersifat toksit akut. Elemen merkuri mempunyai waktu tinggal yang relatif pendek pada tubuh manusia tetapi persenyawaan methyl mercury tinggal pada tubuh manusia 10 kali lebih lama dibandingkan merkuri berbentuk metal. Hal ini dapat menyebabkan tidak berfungsinya otak, gelisah, ginjal, dan kerusakan liver pada kelahiran [10].

\section{KESIMPULAN}

Konsentrasi total merkuri pada air sungai di lima titik pengambilan sampel mulai dari hulu sampai hilir sungai batas Desa Tambang Sawah berturut-turut yaitu $<0,0003 ; 0,0004 ; 0,0007 ; 0,0008$ dan 0,0011 ppm. Konsentrasi total merkuri pada sedimen sungai di lima titik pengambilan sampel mulai dari hulu sampai hilir sungai batas Desa Tambang Sawah berturut-turut yaitu 1,$34 ; 4,18$. 35,89; 50,32 dan 114,37 ppm. Dari hasil penelitian di dapat konsentrasi merkuri pada air sungai dan sedimen sungai dari hulu sampai hilir sungai batas Desa Tambang Sawah semakin meningkat karena akumulasi kegiatan pertambangan emas rakyat yang menggunakan merkuri dan melepas limbahnya ke sungai.

\section{DAFTAR PUSTAKA}

[1]. Sualang, F.H. (2001). Kondisi, Permasalahan Pertambangan Emas trehadap Lingkungan Hidup di Propinsi Sulawesi Utara. Makalah disampaikan pada seminar sehari "Dampak Penambangan Emas Dengan Menggunakan Merkuri Terhadap Kesehatan Manusia". Manado.

[2]. Blanchette, M. C., T. P. Haynes., Y. T. J Kwong., M. R Anderson., G. Veinott., J. F. Payne., C. Stirling and P. J. Sylvester. (2001). A Chemical and Ecotoxilogical Assessment of the Impact of Marine Tailing and Mine

Juli 2020 Vol. 4 No. 2 
Waste '01. Balkema, Rotterdam:323331

[3]. Cai, Y., R. Jaffe'., and R. Jones. 1997. Ethylmercury in the Soils and Sediments of the Florida Everglades. Environ Sci Technol; 31:302- 5.

[4]. Setiabudi, T. B. (2005). Penyebaran Merkuri Akibat Usaha Pertambangan Emas di Daerah Sangon, Kabupaten Kulon Projo, D. I Jogjakarta. Kolokium Hasil Lapangan. DIM.

[5]. Anonim. Preventive Measures Against Environment Mercury Pollution and Its Health Effects. Japan Public Health Association. Japan. 112 pp. 2001.

[6]. Harahap, (1991). Toxicity of marine organism caused by polutan. Dalam: Marine pollution and sea life. FAO. Fishing News Book Ltd, Surrey England. 584-594.
[7]. Rochyatun (1997). Diktat Pengantar mata Kuliah Toksikologi Logam Berat. Fakultas Perikanan Brawijaya. Malang.

[8]. Veiga, M. M. and J. A. Meech. (1995). HfEx-A Heuristic on Mercury pollution in the Amazone. Water, Air and Soil Pollution. Vol 80 : 123-132.

[9]. Arief R., Sukandar M., Putra C., Budhiastuti S.E., Misdawarni dan Suratno (2011). Penelitian Geologi Medis Daerah Lebong Tambang Kabupaten Lebong, Provinsi Bengkulu. Prosiding Pusat Sumber Daya Geologi.

[10]. Yulianti R., Sukiyah E., dan Sulaksanak N. (2016). Dampak Limbah Penambangan Emas Tanpa Izin (PETI) Terhadap Kualitas Air Sungai Limun Kabupaten Sarolangun Propinsi Jambi. Scientific Contribution UNPAD. Bandung 